\section{Evaluation and comparison of four protein extraction protocols for mono- and two- dimensional electrophoresis in Mytilus galloprovincialis}

\author{
Marina Ceruso, Claudia Chirollo, Federica \\ Boccia, Giorgio Smaldone, Raffaele \\ Marrone, Tiziana Pepe \\ Department of Veterinary Medicine and \\ Animal Production, University of Naples \\ Federico II, Italy
}

\section{Abstract}

In this study, four protein extraction protocols from Mytilus galloprovincialis were evaluated with the aim to identify the most practical, efficient and reproducible method. Four extraction protocols frequently used for mussels and organic matrices were selected and compared. The methods were based on the use of: i) TRIzol reagent; ii) Lysis buffer; iii) phenylmethanesulfonyl fluoride; iv) trichloroacetic acid-acetone. Protein concentration was measured by the Bradford method. Three specimens of mussels were studied and the analysis was conducted in triplicate for each of the four protocols. Results indicated that the four methods could extract significantly different protein profiles. The highest number of protein spots resolved in 2DE gels and the best reproducibility was obtained using trichloroacetic acid-acetone protocol. Results afforded the selection of a suitable extraction protocol to be used for ecotoxicoproteomics studies from mussels and for other proteomic studies conducted by particularly complex tissues such as Mytilus galloprovincialis.

\section{Introduction}

In recent years proteomics has been used for fish and fish products with several aims. Analysis of the water-soluble muscle proteins from aquaculture and wild fish was used to show the fish breeding effects on seafood quality (Monti et al., 2005; Carrera et al., 2007). Proteomics allowed to elucidate the influence of internal organ colonization by Moraxella spp. in organs of Sparus aurata (Addis et al., 2010) and has been considered as a tool for species identification in seafood products, producing interesting results (Piñeiro et al., 1999, 2001; López et al., 2002; Pepe et al., 2010, 2012; Chen and Huang, 2011). Bivalves, and mussels in particular, are good indicators of marine and estuarine pollution, and so they have been widely used in biomonitoring programs in many UE countries (Apraiz et al., 2006).

An accurate and reproducible extraction of proteins is a critical step for proteomics analysis. The criteria for the assessment of protein extraction quality include protein yield, compatibility with IEF, protein spots resolution in a 2DE gel, matched protein spots in replicate gels and reproducibility (Wu et al., 2013).

The aim of this work was to evaluate the efficacy and the reproducibility of four protein extraction protocols for Mytilus galloprovincialis. The extraction methods were selected among the most frequently used for mussels and other experimental animal tissues.

\section{Materials and Methods}

Three specimens of Mytilus galloprovincialis were studied for quality assessment of each selected protein extraction protocol. Each step of the analysis was conducted in triplicate. The flesh (muscle, digestive gland, gills, mantle and intra-valvular liquid) of each $M$. galloprovincialis specimen, were reduced into homogeneous powder under liquid nitrogen and divided into four aliquots (1 g each) for protein extraction. Proteins were extracted using the four following protocols: i) TRIzol reagent (Lee and Lo, 2008; Young and Truman, 2012; Wu et al., 2013); ii) Lysis buffer (Molloy et al., 1998; Lopez et al., 2002; Chen and Huang, 2011; Zhu et al., 2012); iii) Phenylmethanesulfonyl fluoride (PMSF) (Pepe et al., 2010); iv) Trichloroacetic acid-acetone (Shrader et al., 2003; McDonagh and Sheehan, 2007; Keyvanshokooh et al., 2009).

\section{TRIzol reagent extraction}

The ground sample was re-suspended in 1 $\mathrm{mL}$ TRIzol reagent and centrifuged at $12,000 \mathrm{~g}$ for $5 \mathrm{~min}$ at $4^{\circ} \mathrm{C}$. The supernatant was added with $200 \mu \mathrm{L}$ chloroform before being shaken vigorously for $3 \mathrm{~min}$ and precipitated at room temperature for $3 \mathrm{~min}$. This mixture was then centrifuged at $12,000 \mathrm{~g}$ for $15 \mathrm{~min}$ at $4^{\circ} \mathrm{C}$ and the upper aqueous phase was discarded. Then, $300 \mu \mathrm{L}$ of absolute ethyl alcohol was added to the lower organic phase and the mixture was allowed to stand for $3 \mathrm{~min}$ at room temperature before being centrifuged at $2000 \mathrm{~g}$ for $5 \mathrm{~min}$ at $4^{\circ} \mathrm{C}$. The phenol/ethanol supernatant was precipitated for at least $30 \mathrm{~min}$ at room temperature by the addition of $750 \mu \mathrm{L}$ isopropanol prior to centrifugation at $14,000 \mathrm{~g}$ for $10 \mathrm{~min}$ at $4^{\circ} \mathrm{C}$. The supernatant was removed, and the pellet was washed twice using $1 \mathrm{~mL}$ ethanol (v/v 95\%) and centrifuged at $14000 \mathrm{~g}$ for $10 \mathrm{~min}$ at $4^{\circ} \mathrm{C}$. The pellets were solubilised in the lysis buffer (7 M urea, 2 M thiourea, 4\% m/v CHAPS,
Correspondence: Marina Ceruso, Department of Veterinary Medicine and Animal Production, University of Naples Federico II, via Delpino 1, 80137 Naples, Italy.

Tel. +39.081.2533905 - Fax: +39.081.292981.

E-mail: marina.ceruso@gmail.com

Key words: Proteomics; Protein extraction; Mytilus galloprovincialis.

Conflict of interest: the authors declare no potential conflict of interest.

Received for publication: 9 July 2014.

Revision received: 12 January 2015.

Accepted for publication: 13 January 2015.

This work is licensed under a Creative Commons Attribution 3.0 License (by-nc 3.0).

(C) Copyright M. Ceruso et al., 2015

Licensee PAGEPress, Italy

Italian Journal of Food Safety 2015; 4:4534

doi:10.4081/ijfs.2015.4534

$65 \mathrm{mM}$ DTT) and then incubated for $3 \mathrm{~h}$ at room temperature. The homogenate was centrifuged at 12,000 $\mathrm{g}$ for $10 \mathrm{~min}$ and the supernatant was applied to electrophoresis.

\section{Lysis buffer extraction}

Proteins were extracted by suspending the powdered samples in Lysis buffer (7 M urea; 2 M thiourea; $40 \mathrm{mM}$ Tris; 4\% w/v CHAPS; $65 \mathrm{mM}$ DTT). The mixture was shaken vigorously at room temperature for $2 \mathrm{~h}$, centrifuged at $14,000 \mathrm{~g}$ for $30 \mathrm{~min}$ and the supernatant was used for electrophoresis.

\section{Phenylmethanesulfonyl fluoride- based method}

In this method, the powdered tissue was dipped in $2 \mathrm{~mL}$ of $10 \mathrm{mM}$ Tris-HCl buffer at $4^{\circ} \mathrm{C}$, pH 7.2, supplemented with $5 \mathrm{mM}$ PMSF (phenylmethanesulfonylfluoride) and centrifuged at $15,000 \mathrm{~g}$ at $4^{\circ} \mathrm{C}$ for $20 \mathrm{~min}$. The supernatant was then recovered, filtered using Ultrafree CL $(0.22 \mu \mathrm{m})$ filters, and stored at $-20^{\circ} \mathrm{C}$ until analysis by electrophoresis.

\section{Trichloroacetic acid-acetone extraction}

The trichloroacetic acid-acetone extraction, based on the most frequently used extraction protocol for experimental animal samples, was applied with some modifications. The powdered sample was re-suspended in cold buffer $(10 \% \mathrm{w} / \mathrm{v}$ TCA in acetone contained $0.07 \% \mathrm{w} / \mathrm{v}$ DTT), precipitated at $-20^{\circ} \mathrm{C}$ overnight and centrifuged at $15,000 \mathrm{~g}$ for $30 \mathrm{~min}$ at $4^{\circ} \mathrm{C}$. The supernatant was discarded and the pellet was re-suspended two times with cold acetone containing $0.07 \% \mathrm{w} / \mathrm{v}$ DTT, kept at $-20^{\circ} \mathrm{C}$ for $1 \mathrm{~h}$ and centrifuged at $15,000 \mathrm{~g}$ for $30 \mathrm{~min}$ at $4^{\circ} \mathrm{C}$. The pellet was solubilized in the lysis buffer (7 M 
DTT and $0.2 \%$ W/N Bio-lyte buffer), the suspension was incubated for $3 \mathrm{~h}$ at room temperature, centrifuged at 12,000 $\mathrm{g}$ for $10 \mathrm{~min}$ and the supernatant was applied to electrophoresis.

Protein concentration was measured by the Bradford method (Bradford, 1976) using bovine serum albumin as standard. Proteins $(50 \mu \mathrm{g})$ were separated on a $12.5 \%(\mathrm{w} / \mathrm{w})$ polyacrylamide gel $(10 \mathrm{~cm} \times 8 \mathrm{~cm} \times 0.75 \mathrm{~mm})$ at $10^{\circ} \mathrm{C}$ with $25 \mathrm{~mA} / \mathrm{gel}$ constant current until the dye front reached the bottom of the gel, according to Hochstrasser et al. (1988). Gels were stained for 50 min with Coomassie Brilliant Blue R-250 and destained with MilliQ grade water.

The first dimensional electrophoresis (isoelectric focusing, IEF) was carried out on nonlinear wide-range immobilized $\mathrm{pH}$ gradients (pH 3-10; 7 cm long IPG strips; GE Healthcare, Uppsala, Sweden) using the Protean $112^{\text {TM }}$ IEF System (Biorad). Analytical-run IPG-strips were rehydrated with $200 \mu \mathrm{g}$ of total proteins in $125 \mu \mathrm{L}$ of rehydratation buffer and $0.2 \%$ $(\mathrm{v} / \mathrm{v})$ carrier ampholyte for $12 \mathrm{~h}$, at $50 \mathrm{~mA}$ at $20^{\circ} \mathrm{C}$. The strips were then focused according to the following electrical conditions at $20^{\circ} \mathrm{C}$ : $250 \mathrm{~V}$ for $15 \mathrm{~min}, 4000 \mathrm{~V}$ for $1 \mathrm{~h}, 4000 \mathrm{~V}$ until a total of $15000 \mathrm{~V}$ was reached. For preparative gels $200 \mu \mathrm{g}$ of total proteins were used. After focusing, analytical and preparative IPG strips were equilibrated for $15 \mathrm{~min}$ in $6 \mathrm{M}$ urea, $30 \%$ (V/V) glycerol, 2\% (w/N) SDS, $0.05 \mathrm{M}$ Tris-HCl, $\mathrm{pH} 6.8,1 \%(\mathrm{w} / \mathrm{V})$ DTT, and subsequently for 15 min in the same urea/SDS/Tris buffer solution but substituting the $1 \%(\mathrm{w} / \mathrm{V})$ DTT with $2.5 \%$ $(w / V)$ iodoacetamide. The second dimension was carried out on $12 \%$ (w/w) polyacrylamide gels $(10 \mathrm{~cm} \mathrm{x} 8 \mathrm{~cm} \times 0.75 \mathrm{~mm})$ at $25 \mathrm{~mA} / \mathrm{gel}$ constant current and $10^{\circ} \mathrm{C}$ until the dye front reached the bottom of the gel, according to Hochstrasser et al. (1988). Gels were stained for 50 min with Coomassie Brilliant Blue R250 and destained with MilliQ grade water.

\section{Results}

Results showed that Lysis buffer, trichloroacetic acid-acetone, TRIzol reagent and PMSF based extractions could extract significantly different protein profiles from Mytilus galloprovincialis. In particular, protein concentration measured by the Bradford method showed the best yield and reproducibility for trichloroacetic acid-acetone (Table 1).

SDS-PAGE and two-dimensional electrophoresis allowed a better evaluation and comparison of the efficacy of the four extraction protocols. The comparison confirmed differences also in the yields and in the purity of protein patterns. The method gave the maxi-

- Lane 1 - Lane 2 Lane $3^{2}$ Lane mum reproducibility, the better compatibility to IEF and the most protein spots resolved in 2DE gels for M. galloprovincialis.

(Pepe et al., 2010), showed a good yield but poor reproducibility as SDS-page showed high definition only in one replication. Using the IEF procedure difficulties in current passage (Figure 1) and as a consequence less spots were pointed out in 2DE images. This may be due to a poor compatibility between a very simple extraction method and a heterogeneous and complex sample as Mytilus galloprovincialis. Lysis buffer, even though it is one of the most common protein extraction method used for tissues for its rapid execution (Molloy et al., 1998; Lopez et al., 2002; Chen and Huang, 2011; Zhu et al., 2012), showed a low reliability and reproducibility. Moreover, the protein extract, at the visual examination, was non homogeneous, dark and matt. terms of reproducibility, yield, high protein definition in SDS-page and good compatibility to IEF (Figure 1). Better results in comparison with the other extraction protocols, both in number and resolution of the spots were shown also at 2DE analysis.

If compared with the other methods, the TCA acetone extraction protocol requires more time and is more complex. The TRIzol based is an easier technique and allowed good results for both SDS-page and IEF even if the yield in 2DE analysis was lower than that obtained with TCA acetone. The PMSF method, generally used in proteomics studies of fish muscle

\section{Conclusions}

Four extraction methods were evaluated and compared for the whole proteome analysis of Mytilus galloprovincialis. The extraction of the whole mussels, and not of single tissue, allowed a global vision of the proteome and therefore provided a better chance to identify proteins of interest. On the whole the best results in terms of yield, reproducibility and

Table 1. Protein concentration $(\mu \mathrm{L})$ of the extracts measured by the Bradford method.

\begin{tabular}{llccc} 
Protocols & \multicolumn{3}{c}{$\begin{array}{c}\text { Extracts } \\
\text { First sample }\end{array}$} & $\begin{array}{c}\text { Second sample } \\
\text { Third sample }\end{array}$ \\
\hline 1 & TRIzol & 2.9 & 0.29 & 2.2 \\
2 & Lysis buffer & 20.5 & 58.8 & 17.67 \\
\hline 3 & PMSF & 21.1 & 0.27 & 0.21 \\
4 & TCA-acetone & 25.8 & 23.8 & 20.4 \\
\hline
\end{tabular}

PMSF, phenylmethanesulfonyl fluoride; TCA, trichloroacetic acid. Values are expressed as $\mu \mathrm{g} / \mu \mathrm{L}$.

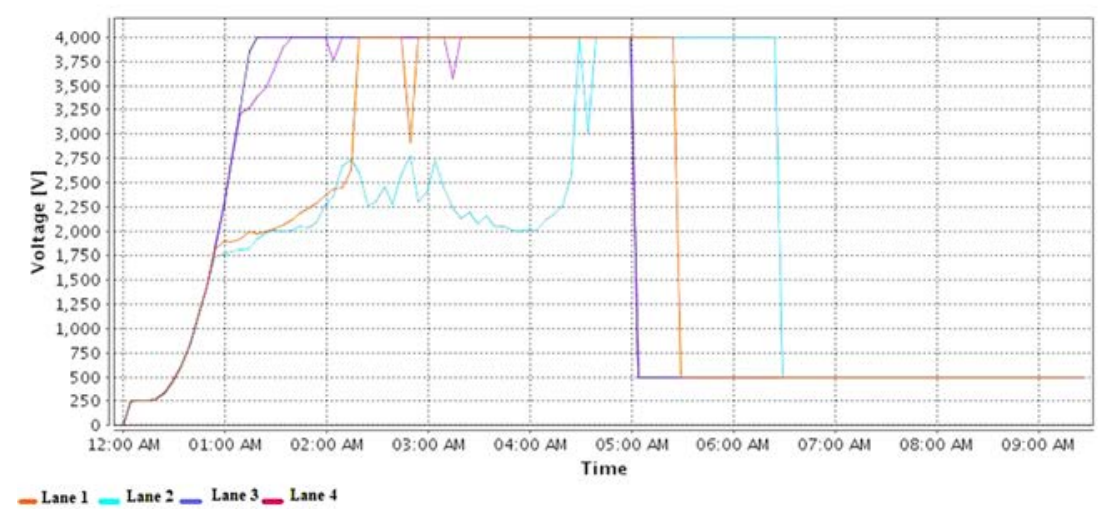

Figure 1. Isoelectric focusing showed difficulties in current passage for TRIzol and Lysis buffer extracts. Phenylmethanesulfonyl fluoride and trichloroacetic acid-acetone extracts displayed the best compatibility to isoelectric focusing. Lane 1, TRIzol; lane 2, Lysis buffer; lane 3, phenylmethanesulfonyl fluoride; lane 4, trichloroacetic acid-acetone. 
accuracy were obtained employing the TCAacetone extraction protocol. Results from this study contribute to increasing the information on quality and reproducibility of protein extraction techniques from complex food matrices, such as $M$. galloprovincialis, since the availability and reliability of protocols which allow a correct data interpretation is retained of the utmost importance for future proteomic work on mussels.

\section{References}

Addis MF, Cappuccinelli R, Tedde V, Pagnozzi D, Viale I, Meloni M, Salati F, Roggio T, Uzzau S, 2010. Influence of Moraxella sp. colonization on the kidney proteome of farmed gilthead sea breams (Sparus aurata, L.). Proteome Sci 8:1-8.

Apraiz I, Mi J, Cristobal S, 2006. Identification of proteomic signatures of $\mathrm{e}$ xposure to marine pollutants in mussels (Mytilus edulis). Mol Cell Proteomics 5:1274-85.

Bradford MM, 1976. A rapid and sensitive method for the quantitation of microgram quantities of protein utilizing the principle of protein-dye binding. Anal Biochem 72:248-54.

Carrera M, Cañas B, Piñeiro C, Vázquez J, Gallardo JM, 2007. De novo mass spectrometry sequencing and characterization of species-specific peptides from nucleoside diphosphate kinase B for the classification of commercial fish species belonging to the family Merlucciidae. J Proteome Res 6:3070-80.

Chen HB, Huang HQ, 2011. Proteomic analysis of methyl parathion-responsive proteins in Sparus latus liver. Fish Shellfish Immun 30:800-6.

Hochstrasser D, Augsburger V, Pun T, Weber D, Pellegrini C, Muller AF, 1988. "High-reso- lution" mini-two-dimensional gel electrophoresis automatically run and stained in less than $6 \mathrm{~h}$ with small, ready-to-use slab gels. Clin Chem 34:166-70.

Keyvanshokooh P, Vaziri B, Gharaei A, Mahboudi F, Esmaili-Sari A, ShahriariMoghadam M, 2009. Proteome modifications of juvenile beluga (Huso huso) brain as an effect of dietary methylmercury. Comp Biochem Phys D 4:243-8.

Lee FW, Lo SC, 2008. The use of Trizol reagent (phenol/guanidine isothiocyanate) for producing high quality two-dimensional gel electrophoretograms (2-DE) of dinoflagellates. J Microbiol Method 73:26-32.

Lopez JL, Marina A, Vazquez J, Alvarez G, 2002. A proteomic approach to the study of the marine mussels Mytilus edulis and M. galloprovincialis. Mar Biol 141:217-23.

McDonagh B, Sheehan D, 2007. Effect of oxidative stress on protein thiols in the blue mussel Mytilus edulis: Proteomic identification of target proteins. Proteomics 7:3395-403.

Molloy MP, Herbert BR, Walsh BJ, Tyler MI, Traini M, Sanchez JC, Hochstrasser DF, Williams KL, Gooley AA, 1998. Extraction of membrane proteins by differential solubilization for separation using $\mathrm{t}$ wo-dimensional gel electrophoresis. Electrophoresis 19:837-44.

Monti G, De Napoli L, Mainolfi P, Barone R, Guida M, Marino G, Amoresano A, 2005. Monitoring food quality by microfluidic electrophoresis, gas chromatography, and massspectrometry techniques: effects of aquaculture on the sea bass (Dicentrarchus labrax). Anal Chem 77: 2587-94.

Pepe T, Ceruso M, Carpentieri A, Ventrone I, Amoresano A, Anastasio A, 2010. Proteomic analysis for the identification of Thunnus genus three species. Vet Res Commun 34:153-5.

Pepe T, Ceruso M, Carpentieri A, Ventrone I,
Amoresano A, Anastasio A, Cortesi ML, 2012. Differentiation of four tuna species by two-dimensional electrophoresis and mass spectrometric analysis. In: Heazlewood J, ed. Proteomics. Applications in biology. InTech, Rijeka, Croatia, pp 191-208.

Piñeiro C, Barros-Velázquez J, Pérez-Martín RI, Martínez I, Jacobsen T, Rehbein $\mathrm{H}$, Kündiger $\mathrm{R}$, Mendes $\mathrm{R}$, Etienne M, Jerome M, Craig A, Mackie IM, Jessen F, 1999. Development of a sodium dodecyl sulfate-polyacrylamide gel electrophoresis reference method for the analysis and identification of fish species in raw and heat-processed samples: a collaborative study. Electrophoresis 20:1425-32.

Piñeiro C, Vázquez J, Marina AI, BarrosVelázquez J, Gallardo JM, 2001. Characterization and partial sequencing of species-specific sarcoplasmic polypeptides from commercial hake species by mass spectrometry following two-dimensional electrophoresis. Electrophoresis 22: 1545-52.

Shrader EA, Henry TR, Greeley MS, Bradley BP, 2003. Proteomics in Zebrafish exposed to endocrine disrupting chemicals. Ecotoxicology 12:485-8.

Wu H, Ji C, Wei L, Zhao J, 2013. Evaluation of protein extraction protocols $\mathrm{f}$ or 2DE in marine ecotoxicoproteomics. Proteomics 13:3205-10.

Young C, Truman P, 2012. Proteins isolated with TRIzol are compatible with twodimensional electrophoresis and mass spectrometry analyses. Anal Biochem 421:330-2.

Zhu B, Gao K, Wang K, Ke C, Huang H, 2012. Gonad differential proteins revealed with proteomics in oyster (Saccostrea cucullata) using alga as food contaminated with cadmium. Chemosphere 87:397-403. 